\title{
SOME REMARKS REGARDING THE MANOMETRIC DETERMINATION OF PYRIDOXAL PHOSPHATE
}

\author{
TH. W. DONKERLO* \\ Laboratory for Physiological Chemistry, The University, \\ Utrecht (The Netherlands) \\ (Received July I5th, 1963)
}

\begin{abstract}
SLIMMARY
In the manometric determination of pyridoxal phosphate (Gunsalus AND SMITH) continuous careful protection of the solutions from light is required. Stock solutions can be kept for at least one month if stored in the dark.

Pyridoxal phosphate added to alkaline extracts of myocardial tissue of rats could not be recovered completely. Therefore an internal standard was used. In this way we found in hearts of normal healthy rats an avcrage of $4.6 \mu$ g pyridoxal phosphate per $\mathrm{g}$ wet tissue.
\end{abstract}

When determining the quantities of pyridoxal phosphate in rat heart tissue, we were unable at first to obtain reproducible standard curves. In this connection we wish to indicate some measures and precautions that in our experience are necessary in this determination.

We used the method of Gunsalus and SMith ${ }^{1}$, in which the carbon dioxide liberated in the reaction scheme mentioned below is a measure of the amount of added pyridoxal phosphate:

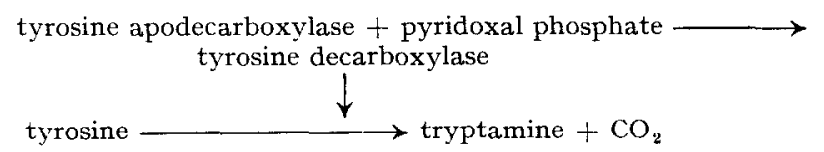

The tyrosine apodecarboxylase was obtained from Streptococcus faecalis strain $\mathrm{S}$ cultivated in a vitamin $\mathrm{B}_{6}$-free medium.

\section{METHOD}

\section{Photosensitivity of pyridoxal phosphate solutions}

In the literature the photosensitivity of pyridoxal phosphate is only occasionally mentioned.

We noticed that a yellow alkaline solution became colourless after exposure to light for some time. In a strongly alkaline medium, pyridoxal phosphate has an absorption maximum at $388 \mathrm{~m} \mu$, which is associated with the aldehyde group in the 4-posi-

* Present address: University Hospital, Dept. of Cardiology, Utrecht, The Netherlands. 
tion. By measuring the decrease of the absorbancy at this wavelength under the influence of light, we ascertained that after $2 \mathrm{~h}$ more than half of the pyridoxal phosphate had been converted to another compound, with an absorption maximum in that medium at about $300 \mathrm{~m} \mu$ (see Table I).

TABLE I

INFLUENCE OF DAYLight ON A SOLUTION OF PYRIDOXAL PHOSPHATE IN O.I $N$ NaOH $(20.2 \mu \mathrm{g} / \mathrm{ml})$, NOT PLACED IN DIRECT SUNLIGHT

\begin{tabular}{cc}
\hline Time (hours) & $\begin{array}{c}\text { Absorbancy } \\
388 m \mu\end{array}$ \\
\hline $\mathrm{O}$ & $0.4 \mathrm{I} 3$ \\
$\mathrm{I}$ & 0.265 \\
$\mathrm{I}$ & 0.202 \\
$4 \frac{3}{4}$ & 0.082 \\
$5 \frac{3}{4}$ & 0.062 \\
\hline
\end{tabular}

TABLE II

DECREASE OF THE ABSORBANCY OF A SOLUTION OF PYRIDOXAL PHOSPHATE IN O.I $N$ NaOH, STORED IN THE DARK

\begin{tabular}{cc} 
Date & $\begin{array}{c}\text { Absorbancy } \\
388 m \mu\end{array}$ \\
\hline $20-7$ & 0.434 \\
$2 \mathrm{I}-7$ & 0.430 \\
$15-8$ & 0.433 \\
$22-8$ & $0.43 \mathrm{I}$ \\
$22-9$ & 0.424 \\
$4-10$ & $0.42 \mathrm{I}$ \\
$7-\mathrm{IO}$ & $0.42 \mathrm{I}$ \\
$2 \mathrm{I}-\mathrm{II}$ & $0.4 \mathrm{I} 2$ \\
\hline
\end{tabular}

TABLE III

$Q_{\mathrm{CO}_{1}}$ OBTAINED WITH SOME STANDARD SOLUTIONS OF PYRIDOXAL PHOSPHATE

\begin{tabular}{|c|c|c|c|}
\hline \multirow{2}{*}{$\begin{array}{l}\text { Pyridoxal phosphate } \\
\text { (mpg/Warburg vessel) }\end{array}$} & \multicolumn{3}{|c|}{$Q_{\mathrm{CO}_{2}}\left(\mu l, 27^{\circ}\right)$} \\
\hline & Mean & Range & $\begin{array}{c}\text { Number of } \\
\text { determinations }\end{array}$ \\
\hline 5 & I 58 & $150-162$ & 5 \\
\hline 10 & 312 & $282-330$ & 5 \\
\hline I 5 & $47^{\circ}$ & $45^{0}-495$ & 3 \\
\hline
\end{tabular}

Thus we realised that far too much light had been admitted during the various procedures of the determination, such as pipetting, diluting, etc. Henceforth this was avoided in the following manner.

I. The stock solution (in o.I $N \mathrm{NaOH}$ ) was kept in a tube painted black, in the refrigerator. If desired the extinction could be checked before each new determination. A solution kept in this fashion remained unchanged for at least one month (see Table II).

2. The standard solutions were always kept in an opaque, covered container (filled with ice), and were only taken out for a short moment while pipetting.

3. The Warburg vessels were kept under a black cover until they were placed in the water bath. 
4. The tubes with tissue extracts were placed in a wooden block in which holes of sufficient depth were bored. The final dilutions were stored in the ice container.

5. All the work was done in subdued light.

With these precautions we obtained reproducible values (see Table III). The production of carbon dioxide in the afore-mentioned reaction scheme proceeds linearly during the first $\mathrm{I}_{5} \mathrm{~min}$ and then falls off. In calculating the $Q_{\mathrm{CO}}$ we have therefore only used the $\mu \mathrm{l} \mathrm{CO} 2$ liberated after 5 , ro and $\mathrm{I}_{5} \mathrm{~min}$.

\section{Determination of pyridoxal phosphate in tissue}

Pyridoxal phosphate can be obtained in free form from a tissue homogenate in o.I $N \mathrm{NaOH}$ by heating for Io min in a water bath at $100^{\circ}$. When the mixture is acidified to the required pH of $\mathbf{5 . 5}$, a coagulum is formed but this does not absorb pyridoxal phosphate. Therefore the precipitate was not removed by centrifuging, in order to prevent unnecessary exposure to light. In 20 determinations in myocardial tissue of Wistar rats we recovered an average of $82 \%(69 \%-108 \%)$ of synthetic pyridoxal phosphate that had been added to the alkaline tissue extract. This incomplete recovery made it necessary to work with an internal standard. For a single determination one therefore has to measure the $Q_{\mathrm{CO}_{2}}$ of

(I) a blank (all reagents, with buffer solution replacing pyridoxal phosphate),

(2) a standard solution (5 $\mathrm{m} \mu \mathrm{g}$ per Warburg vessel),

(3) diluted tissue extract,

(4) diluted tissuc cxtract plus standard solution.

Then we obtain:

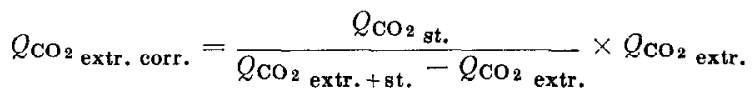

From $Q_{\text {conextr. corr. }}$ it is possible to calculate, with the aid of the standard curve constructed from the data in Table III, the real amount of pyridoxal phosphate in each Warburg vessel.

From the equation one can see that the standard solution does not necessarily have to contain an exactly known amount of the compound. To indicate the degree of reproducibility of the determination, we may mention that in 3 identical portions of one homogenate of myocardium we found amounts of $3 . \mathrm{I}, 3.9$ and $4.3 \mu \mathrm{g}$ per g wet tissue.

\section{DISCUSSION}

In the instructions of Gunsalus and SMith ${ }^{1}$ the necessity for the exclusion of light is not mentioned. Boxer, Pruss and GoodharT ${ }^{2,3}$ state that their stock solutions can be kept for a week if stored cool and in the dark. LABouesse, Chatagner and JOLLÈs-BERGERET ${ }^{4,5}$ always prepare a new stock solution before each determination, because it cannot be stored without decomposition, even at $-20^{\circ}$. They do not indicate the need to exclude light. In our experience this is absolutely essential throughout the whole procedure. Even in an acid medium, which is said to have an adverse influence on the stability ${ }^{4}$, we found no decrease in activity after 5 days, if kept in the dark.

In Io normal healthy Wistar rats, we found $4.6 \pm \mathrm{I} .7 \mu \mathrm{g}$ of pyridoxal phosphate 
per $g$ wet heart tissue (mean \pm S.D.). These values are noticeably higher than those found by others ${ }^{6-8}(0.83 \mu \mathrm{g}, \mathrm{I} .08 \mu \mathrm{g}$ and $0.82 \mu \mathrm{g}$ respectively). We cannot give an explanation for these differences.

\section{ACKNOWLEDGEMENT}

I am most obliged to Prof. Dr. K. C. Winkler (Laboratory of Microbiology, The University, Utrecht, The Netherlands) for preparing the tyrosine apodecarboxylase.

\section{REFERENCES}

1 I. C. Gunsalus and R. A. Smith, in Methods in Enzymology, Part II, Academic Press Inc. New York, 1955, p. 963.

2 G. E. Boxer, M. P. Pruss and R. S. Goodhart, J. Nutr., 63 (1957) 623.

${ }^{3}$ G. E. BOXER, personal communication (I960).

4 J. Labouesse, F. Chatagner et B. Jollès-Bergeret, Biochim. Biophys. Acta, 39 (ig6o) 372.

5 J. Labouesse, personal communication (rg60).

- P. Fasella, C. Baglioni, C. Turand and N. Silitprandi, Clin. Chim. Acta, 5 (1960) 146.

2 E. Mascitelli-Coriandoli and R. Boldrini, Experientia, I5 (1959) 229.

8 M. Wachstein and C. Moore, Proc. Soc. Exptl. Biol. Med., 97 (1958) 905. 